contribute to a better understanding of Indian history and culture.

- The Newberry Library Associates has published An Uncommon Collection of Uncommon Collections: The Newberry Library. The booklet presents an informal history of The Newber- ry Library and descriptions of the many quality special collections held by the Library. The booklet is available from the Publications Department, The Newberry Library, 60 West Walton Street, Chicago, Illinois 60610 for $\$ 1.00$ per copy.

\title{
News from the Sections
}

ART SUBSECTION

The fourth edition of the Class N, Fine Arts, Library of Congress Classification, has appeared this fall. Thanks to the work of William B. Walker, librarian of the National Collection of Fine Arts/National Portrait Gallery Library and vice-chairman of the Art Subsection, this new issue represents not only an incorporation of all additions and changes made since the third edition up to October 1969, but also a thoroughgoing revision. Perhaps the most striking innovations of this revision are the regrouping of numbers for similar types of publications which had heretofore been dispersed in several places (e.g. works on art collectors and patrons have been brought closer to material on private collections), and the combining, in the same numerical sequence, of works on the history of art in a particular medium with books of reproductions of works in the same medium. In all cases where class numbers are no longer

APPOINTMENTS

Mrs. EMIKo Axiyama, who has been serving as acting librarian of the Cornell Medical College, continues in the library and will henceforth direct all of its service functions.

Mrs. Donna Baker is on the staff of the Tompkins-McCaw library, Health Sciences Division, Virginia Commonwealth University, Richmond, as assistant cataloger.

Mrs. Ivy Bayard is now head librarian, Tyler School of Art library, Temple University, Philadelphia.

Sylvia Belx has been promoted to the position of acquisitions librarian, librarian III, library of Osgoode Hall Law School, York University, Toronto, Ontario, Canada.

Mrs. Gwynnetr H. Bishop is now head of the science and medicine department of the University of Toronto library, Ontario, Canada.

Mrs. Helma Bonfield has been appointed librarian I, cataloging department, York University libraries, Toronto. used by the Library of Congress, they have been parenthesized for continued use by other libraries which may not wish to adopt these changes, and appropriate references have been made. The task of updating the schedules and increasing their comprehensiveness will reap many rewards. A new subclass NX has been added, dealing with the arts in general, including literature and the performing arts as well as the visual arts. The geographic tables which can be applied throughout the schedule have been updated to reflect the current jurisdictional situation. The edition has been printed on one side of the page only, thereby providing a suitable format for libraries using the schedule to make annotations, punch the pages for a looseleaf binder, and insert pages from the $L C$ Classification-Additions and Changes for updating. Copies may be obtained from the Card Division, Library of Congress, Building 159, Navy Yard Annex, Washington, D.C. 20541, at $\$ 3.00$ a copy.

\section{Personnel}

Hartwell Bowsfield is now university archivist, on a part-time basis, at York University libraries, Toronto.

M. Diane Brown has joined the staff of the cataloging department of the York University libraries, Toronto, as librarian I.

Mrs. LouISE BUGG has been promoted to the position of head, catalog department, Kresge library, Oakland University, Rochester, Michigan.

Mrs. Etta S. Bullock has been appointed librarian, community and cultural affairs, Temple University libraries, Philadelphia.

Mrs. Patricia J. Bunker has joined the staff of Rush Rhees library, University of Rochester, New York, as assistant librarian.

Mrs. Nancy BUrich has assumed a position as reference librarian, Medical library, Columbia University.

Ralph L. Carder is in the Library Resources Center, Wright State University, Dayton, Ohio, in the capacity of graphic supervisor and instructor of library administration. 
Joan A. Carruthers has been appointed librarian of the Central library, York University libraries, York University, Toronto.

Roger Cartmal has been named head of technical services at Pratt Institute, Brooklyn, New York.

Terence Wirliam Cassidy has accepted appointment to the position of acquisitions librarian at the Clendening Medical library, University of Kansas Medical Center, Lawrence.

Hyung-Sux ChaI has been appointed head of the Korean section, East Asian library, at Columbia University.

Ru-Siou Chang is the new library assistant I in the East Asiatic library of the University of California, Berkeley.

Mrs. Margarfita P. Childs has joined the staff of the Pennsylvania State University libraries, University Park, as rare books cataloger.

Diane Chmura is now microform librarian at the Gertrude Kistler Memorial library, Rosemont College, Rosemont, Pennsylvania.

Boris T. Chumakov has joined the staff of Central library, York University libraries, Toronto, as librarian I.

Mrs. Joanne P. Chumakov is librarian II, cataloging department, of the York University libraries, Toronto.

William S. CoOper has accepted the position of acting director of the University of California's Institute of Library Research. He will also continue in his present position as acting associate professor of librarianship at the University of California, Berkeley.

Davm Dillard has been named assistant in the business department at Temple University, Temple University libraries, Philadelphia.

LEsLIE EDwards is now head of acquisitions at the library of the State University of New York at Binghamton.

LUCILLE B. EMCH has been named associate director for rare books, special collections, and archives in the University of Toledo libraries, Toledo, Ohio.

H. Marguerite Farris has assumed the position of librarian I, circulation department, library of Osgoode Hall Law School, York University, Toronto.

EdtTh Ferrell has received appointment to the position of reference librarian, social science department, University of Arizona library, University of Arizona, Tucson.

Mrs. Sybil M. Fielder has received appointment to the position of librarian of the Ella Strong Denison library at Scripps College, Claremont, California.

Eugene B. Fleischer has been appointed director of the Learning Resources Center at Ocean County College, Toms River, New Jersey.

Albert Fowlen is in the reserve book de- partment of the Temple University libraries, Philadelphia, as first assistant.

JoHn Fraznen has joined the library staff of the State University of New York at Binghamton as science bibliographer.

William V. Frazier is now a reference librarian, D. H. Hill library, North Carolina State University, Raleigh.

InEne F. Gankoski has joined the staff of the Bowling Green State University library, Bowling Green, Ohio, as assistant head of bibliography.

Richard Gannon has been appointed gifts and exchange librarian at the State University of New York at Binghamton.

RoBent GAyLOR has received appointment to the position of associate university librarian, Kresge library, Oakland University, Rochester, Michigan.

Dr. JoHN T. GILlespie will become acting dean of the Carleton and Winthrop Palmer Graduate Library School, Long Island University, Long Island, New York, on February 1, 1971.

Mrs. Diane Kelly Goon has rejoined the staff of Butler library, Columbia University, as a reference librarian.

Mark M. Gormley has accepted the position of director of libraries at Wayne State University in Detroit, Michigan.

\section{LENDING LIBRARY of}

\section{FILMS}

\section{SLIDES}

\section{TAPES}

\section{PHOTOS}

RECORDS

EXHIBITS

FILMSTRIPS

SCIENTIFIC FILMS

ON FRANCE

Catalogue upon request

F. A. C. S. E. A.

972 5th Avenue, New York City 10021 (2I2) RE 7-9700 
JACK L. GOIT.OBE has been named assistant director for public services at Samuel Paley library, Temple University, Philadelphia.

Mrs. Sally L. Gross is a new assistant librarian in the University of Rochester, New York, Rush Rhees library.

Mrs. Marion Hanscom is collegiate librarian at the library of the State University of New York at Binghamton.

LYNN R. HARD has joined the staff of McGill University libraries; Montreal, Quebec, Canada, as associate librarian for technical services.

Mary M. Hennen is assistant life science librarian and instructor in library science at Purdue University libraries, Lafayette, Indiana.

YvoNNE HrCks is now working for HEW's new Bureau of Libraries and Educational Technology. Her position is in the Bureau's Division of Library Programs.

Wirliam C. Honner has been appointed systems librarian at the D. H. Hill library, North Carolina State University, Raleigh.

MORTON Howard has assumed the position of circulation librarian at the library of the State University of New York at Binghamton.

Mrs. LYNn M. INNerst has been named librarian I, cataloging department, library of Osgoode Hall Law School of York University, Toronto.

The October issue of CRL News incorrectly listed EL.uXN B. JONES as assistant circulation librarian at Columbia University libraries. The correct position was reference librarian, special collections. This was an editor's error.

Mrs. Susan Kallenbach is the new acting head of the search department of the Temple University libraries, Philadelphia.

JEnnY Tseng KaO is on the staff of the University of Arizona library, Tucson, in the capacity of catalog librarian.

Dr. Igon L. Kavass has been appointed professor of law and Jaw librarian at Northwestern School of Law, Chicago, Illinois.

ARLene Keller is now librarian of the College of Engineering and Technology library, Temple University, Philadelphia.

Barbara G. Kile has assumed the position of gifts and exchange librarian and instructor in library science at Purdue University libraries, Lafayette, Indiana.

ANN KNOUFT is a new staff member of the reference department in the University of $\mathrm{Ne}$ vada library, Las Vegas, Nevada.

ROBERT A. KowALSKI is the new acquisitions librarian of the Library Resources Center, Wright State University, Dayton, Ohio.

Dr. Frenerick I. Kuhns is now audiovisual librarian at Heterick Memorial library, Ohio Northern University, Ada.

Mrs. Eleanor LancstafF is on the staff of Pratt Institute, Brooklyn, New York, as circulation librarian.

SUSAN Laturop has been named assistant li- brarian in reference and documents at the State University of New York library at Binghamton.

John P. Lawhence, foreign language bibliographer, has been promoted to librarian III, York University libraries, Toronto.

Mrs. Carol Ann Levene has joincd the staff of the Clendening Medical library, University of Kansas Medical Center, Lawrence, as assistant reference librarian.

ANNE LEVY is now reference librarian at the State University of New York at Binghamton.

DAWN McCaghy has been appointed as a reference librarian on the staff of the Bowling Green State University library, Bowling Green, Ohio.

Sister Mahion McCreesh has moved into a new position as circulation librarian at the Gertrude Kistler Memorial library, Rosemont College, Rosemont, Pennsylvania.

Cleata A. McIntosil has joined the staff of the catalog department at the University of California, Berkeley, as librarian I.

Richand M. Malinski, map librarian, has accepted the promotion to librarian III, York University libraries, York University, Toronto.

Mrs. Ann Maloney has been appointed first assistant, Ambler Campus library, Temple University, Philadelphia.

Julia Mason is in the cataloging department of York University libraries, Toronto, as librarian $\mathrm{I}$.

Mrs. Barbara Maxwel.t has accepted the position of music librarian in the library of the State University of New York at Binghamton.

Ericrm Meyeriof F has been named librarian of the Cornell Medical College library, Cornell University, Ithaca, New York.

Ricrialis A. IfrLeEr has accepted the appointment of director of Tompkins-McCaw library, Health Sciences Division, Virginia Commonwealth University, Richmond.

Mrs. Janet Minnerath is director of Virginia Medical Information Service, based in the Tompkins-McCaw library, Health Sciences Division, Virginia Commonwealth University, Richmond.

Mrs. Shelagh I. Murray is the new librarian II, cataloging department of York University libraries, Toronto.

Mrs. Susan Newman has been named bibliographer, documents acquisitions, at Butler library, Columbia University.

Mrs. InNa Nichols has assumed the position of catalog librarian in the D. H. Hill library of North Carolina State University, Raleigh.

Josepir Z. Nitecki is the new assistant director for technical services at the Samuel Paley library, Temple University, Philadelphia.

Cathierine O'Connell has been appointed assistant director for public services at the Central Michigan University library, Mount Pleasant, Michigan.

Dennis H. Parks is the new assistant refer- 
ence librarian and instructor in library science at Purdue University libraries, Lafayette, Indiana.

Williax Plaxk has been appointed head of the newly formed serial records and binding section of the National Library of Medicine, Bethesda, Maryland.

Cecile Quintal has joined the staff of the serial records and binding section of the $\mathrm{Na}$ tional Library of Medicine, Bethesda, Maryland.

JAMES V. QuLxi.eY is the new librarian of the Leslie Frost library, librarian III, York University libraries, York University, Toronto.

Mrs. E. ANv RAE has accepted the position of librarian II, cataloging department, library of Osgoode Inall Law School, York University, Toronto.

Mrs. Ans G. Ricken has received appointment to the position of librarian II, Steacie Science library, York University libraries, Toronto.

Mrs. Daphne Rolorf has accepted the position of fine arts librarian at the State University of New York at Binghamton.

Nina J. Root has joined the staff of The American Museum of Natural History library, New York, as librarian.

Patricta A. Roshaven has assumed the position of librarian I in the Graduate Social Science library of the University of California.

T. EDward Ross is on the staff of Central library, York University libraries, Toronto, as assistant reference librarian, librarian $\mathrm{I}$.

Louise M. Rountree has accepted appointment to the position of head librarian at Carnegie library of Livingstone College, Salisbury, North Carolina.

Melvin Sappington is the new head of the documents section, social science department, University of Arizona library, Tucson.

William Saunders is a reference librarian/ education bibliographer on the staff of the Temple University libraries, Philadelphia.

Rosalinde Schallen has joined the staff of Heterick Memorial library, Ohio Northern University, Ada, as acquisitions librarian.
Dr. Kurt Schweris has retired as professor of law and law librarian of Northwestern School of Law, Chicago, and has been named Professor of law emeritus.

KareN Seibert has jointed the staff of the humanities department, University of Arizona library, Tucson, as a reference librarian.

Susan A. Sileffield is now editor II in the Bancroft library (Mark Twain Papers) of the University of California, Berkeley.

Bynon Smirh has accepted the position of catalog librarian at the University of Arizona library, Tucson.

Mrs. Patricia Snyder is now science librarian at Wesleyan University, Middletown, Connecticut.

Melville R. Spence has been named director of libraries at Bowling Grcen State University, Bowling Green, Ohio.

Dr. George Wincmester Stone, Jr., has been appointed to the newly created position of dean of university libraries at New York University.

Gary Thompson has been appointed reference librarian at the Ohio Northern University, Heterick Memorial library.

Mrs. Jane Thompson is now serials librarian of the Tompkins-McCaw library, Health Sciences Division, at Virginia Commonwealth University, Richmond.

William Troutman has assumed the position of administrative assistant of the Temple University libraries, Philadelphia.

Patricia Tunnen has been promoted to the position of head of the humanities department at the University of Arizona library in Tucson.

B. SuE WAdE is now assistant systems librarian, librarian III, library systems department, York University libraries, Toronto.

ANN BAKER WARD has been appointed interlibrary center librarian in the D. H. Hill library, North Carolina State University, Raleigh.

Mrs. Mary Erizabeth Watson has been appointed head, librarian III, documents services, at York University, Toronto.

JoHN P. WEBr has accepted the position of

\section{LOOKING FOR \\ ANOTHER}

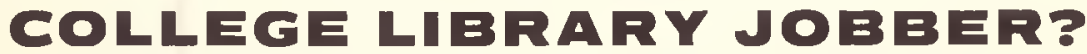

FOR COMPLETE INFORMATION ON OUR SERVICES:

WRITE OR CALL COLLECT: $3 \mid 4-739-3100$

ATTN: MR. LESSER

Midwest Library Service

11400 Dorsett Road

Maryland Heights, Missouri 63043 


\section{NOW YOU CAN GET JANE EYRE ON THE SHELVES AS FAST AS WINNIE THE POOH.}
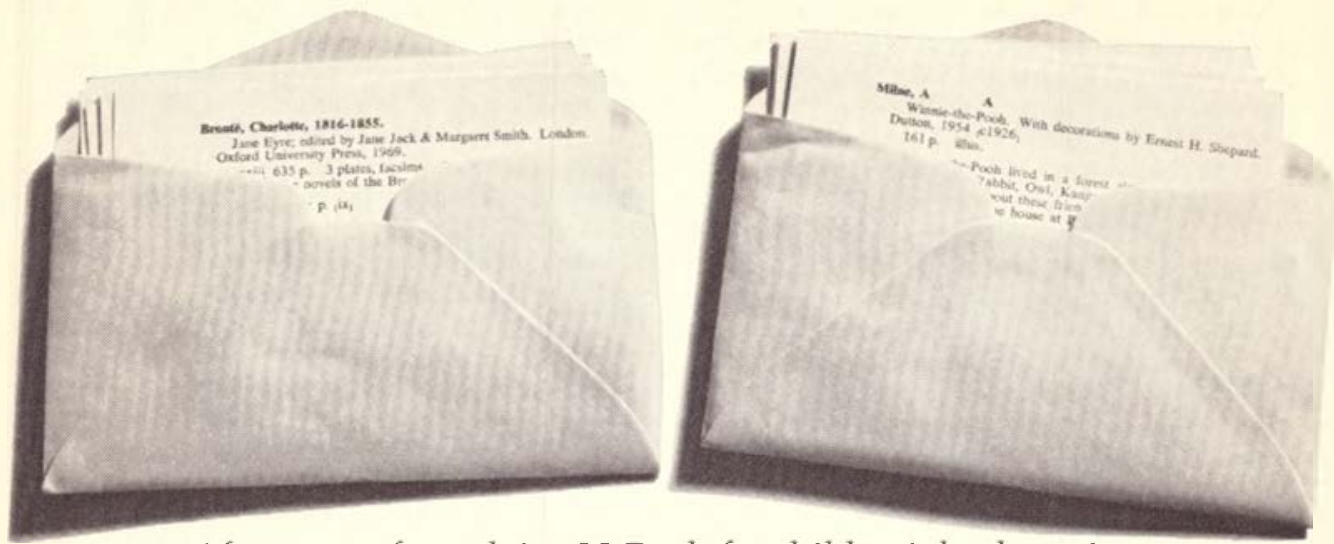

After years of supplying LJ Cards for children's books, we've now grown to adults'.

LJ catalog card sets are now available for all English language adult titles published from 1969 on.

Our adult card sets are designed to accomplish the same thing as LJ processing kits for juvenile titles - namely, to get new acquisitions on the shelves while they're still new.

So, as with all LJ Cards, we guarantee to fill your order within 10 days after receiving it-provided, of course, the book has been published. If we fail, return the order and we'll return your money. (To make sure we don't have to return any money, we've recently increased our orderhandling staff by $250 \%$. And our facilities by $300 \%$.)

You can order adult card sets three ways: with standard Library of Congress order slips; copies of multiple order forms; or any $3^{\prime \prime}$ by 5 slip listing author, title, publisher, date of publication, and edition. The price is $\$ .35$ per set.

And no matter how you do it, you can now have what elementary and high school librarians have had for some time.

An up-to-date reading room. Instead of just an up-to-date storage room. 
consultant and instructor of library administration at the Library Resources Center of Wright State University, Dayton, Ohio.

Elizabeth WIDENMANx has received appointment to the position of cataloger in general cataloging at Butler library, Columbia University.

Brian B. WILKS is acting science librarian, librarian III, of Steacie Science library, York University libraries, Toronto.

WALTER J. WILLARD has been promoted to the position of library assistant I, Biology library, University of California, Berkeley.

Mary F. Williamson has assumed the position of fine arts bibliographer, librarian III, of the York University libraries, Toronto.

Farrt Winger has joined the staff of the Temple University libraries, Philadelphia, as assistant in the catalog department.

Milton T. Wolf received appointment to the position of assistant director of the University Library for General Services and instructor of library administration at Wright State University, Dayton, Ohio.

DaNIEL A. YANCHISIN is a reference librarian in the D. H. Hill library of North Carolina State University, Ralcigh.

WALTER ZIONKowsKY has assumed the position of first assistant in the Conwellana O'Templana department of the Temple University libraries, Philadelphia.

\section{RETIREMENTS}

Miss MyrtLe Bouldin, librarian at Bethel College, McKenzie, Tennessee, retired from her post as of August 31, 1970, after twenty years of service. Miss Bouldin was previously a teacher and a librarian in public schools in Tennessee and Florida.

ROBERT B. Downs, dean of library administration, will retire in September 1971 after twenty-eight years of service at the University of Illinois, Urbana-Champaign.

Professor Frances B. Jenktns of the University of Illinois at Urbana-Champaign will retire from the faculty of the Graduate School of Library Science at the end of January 1971. Mrs. Jenkins has been active in the American Library Association, the American Association for the Advancement of Science, the American Chemical Society, the American Society for Information Science, the Association of American Library Schools, the Medical Library Association, and the Special Library Association. She received the ALA Isadore Gilbert Mudge Citation for distinguished contribution to reference librarianship in 1966 and served on the advisory committee for manpower and training of the National Library of Medicine, 1966-68.

Adeline Steffen has retired from the Memorial Library of the University of Wisconsin after forty-four years of service.
EneEn Thonnton, college librarian of Oberlin College and public librarian of Oberlin Public Library, will retire June 30, 1971. She has served as librarian of Oberlin College since 1956 and has played a major role in the planning of the new central library at Oberlin College.

Miss Margaret Yocom retired August 31, 1970 , as head of the cataloging department at Bowling Green State University Library, after forty-one years of service.

\section{Classified Advertising}

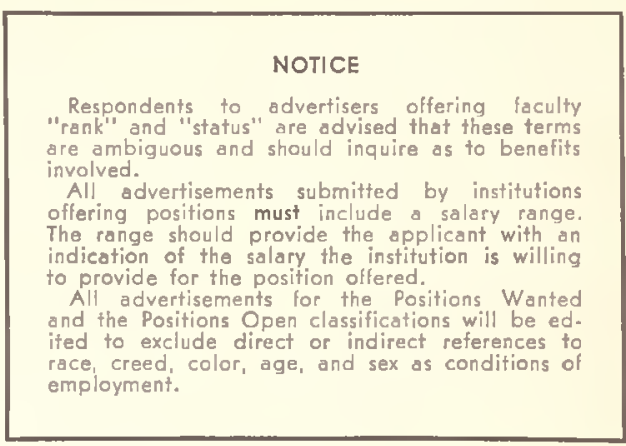

Classified advertising orders and copy, and cancellations, should be addressed to the Advertising Department, 50 East Huron Street, Chicago 60611 , and should reach that office before the tenth of the month preceding publication of issue desired. Copy received after that time may be held for the next issue.

Rate for classified advertising is $\$ 1.25$ per printed line. No additional charge is made for nonmember advertising.

FOR SALE

GOVERNMENT PUBLICATIONS mailed to you within 3 days. SuDocs price plus posfage. Capital Documents Service, Box 4922, Washington 20008.

COLLECIONS. Ronald Firbank first editions: Blasco Ibanez, in English: Vardis Fisher: Lalcadio Hearn first editions: H. L. Mencken first editions: John Dos Passos first editions: Miniature newspapers: Irish pamphlets. For details write William P. Wreden, Dept. "C," P.O. Box 56. Palo Alto CA 94302.

COLLINS, NEW NATURALIST SERIES, 50 vols, complete, all issued, a number out-of-print. Fine, \$250. For details write William P. Wreden, Dept. "C." P.O. Box 56, Palo Alto, CA 94302.

4-UP, 100\% RAG, LC SPECS., perforated card stock for use in Xerox 914 or $720, \$ 22.50 / \mathrm{M}$ delivered. J. Edelen Univ. of South Dakota Library, Vermillion, S.D. 57069.

RADICAL MOVEMENT EPHEMERA. Send for current catalog. Social Science Research, 1012 Blanshard St, Victoria, BC, Canada. 